\title{
Thiazolidinedione use and atrial fibrillation in diabetic patients: a meta-analysis
}

\author{
Zhiwei Zhang ${ }^{1 \dagger}$, Xiaowei Zhang ${ }^{1 \dagger}$, Panagiotis Korantzopoulos ${ }^{2}$, Konstantinos P. Letsas ${ }^{3}$, Gary Tse ${ }^{4,5}$, Mengqi Gong ${ }^{1}$, \\ Lei Meng ${ }^{1}$, Guangping $\mathrm{Li}^{1}$ and Tong Liu ${ }^{1 *}$
}

\begin{abstract}
Background: Accumulating evidence suggests that thiazolidinediones (TZDs) may exert protective effects in atrial fibrillation (AF). The present meta-analysis investigated the association between TZD use and the incidence of AF in diabetic patients.

Methods: Electronic databases were searched until December 2016. Of the 346 initially identified records, 3 randomized clinical trials (RCTs) and 4 observational studies with 130,854 diabetic patients were included in the final analysis.

Results: Pooled analysis of the included studies demonstrated that patients treated with TZDs had approximately $30 \%$ lower risk of developing AF compared to controls [odds ratio (OR): $0.73,95 \%$ confidence interval (CI): 0.62 to $0.87, p=0.0003]$. This association was consistently observed for both new onset AF (OR $=0.77, p=0.002)$ and recurrent $A F(O R=0.41, p=0.002)$, pioglitazone use ( $O R=0.56, p=0.04)$ but not rosiglitazone use $(O R=0.78$, $p=0.12$ ). The association between TZD use and AF incidence was not significant in the pooled analysis of three RCTs $(\mathrm{OR}=0.77,95 \% \mathrm{Cl}=0.53-1.12, p=0.17)$, but was significantly in the pooled analysis of the four observational studies ( $\mathrm{OR}=0.71, p=0.0003)$.

Conclusions: This meta-analysis suggests that TZDs may confer protection against AF in the setting of diabetes mellitus (DM). This class of drugs can be used as upstream therapy for DM patients to prevent the development of AF. Further large-scale RCTs are needed to determine whether TZDs use could prevent AF in the setting of DM.
\end{abstract}

Keywords: Atrial fibrillation, Diabetes mellitus, Thiazolidinediones, Pioglitazone, Rosiglitazone, Meta-analysis

\section{Background}

Atrial fibrillation (AF) is the most prevalent arrhythmia observed in clinical practice, and is associated with significant morbidity and mortality in the popuation. The burden of AF increases over time mainly due to an aging population and to the increasing prevalence of cardiovascular comorbidities. However, strategies to predict and prevent AF are not fully effective [1]. Diabetes mellitus (DM) is one of the strongest independent risk factors for AF incidence, conferring an approximate $40 \%$ higher risk of subsequent $\mathrm{AF}$ development [2,3]. It also predicts

\footnotetext{
* Correspondence: liutongdoc@126.com

${ }^{\dagger}$ Equal contributors

${ }^{1}$ Tianjin Key Laboratory of Ionic-Molecular Function of Cardiovascular Disease, Department of Cardiology, Tianjin Institute of Cardiology, Second Hospital of Tianjin Medical University, No. 23 Pingjiang Road, Hexi District, Tianjin 300211, People's Republic of China

Full list of author information is available at the end of the article
}

the recurrence of AF following a successful direct current cardioversion [4]. Moreover, DM increases the risk of developing stroke, heart failure, and cardiovascular death in patients with AF [5]. Although the exact pathophysiological mechanisms linking DM and AF remain incompletely elucidated, an increasing body of evidence suggests that inflammation and oxidative stress may play an important role [6-8].

Thiazolidinediones (TZDs), a class of peroxisome proliferator-activated receptor- $\gamma$ (PPAR- $\gamma$ ) agonists, are among the most potent insulin-sensitizing drugs [9]. Apart from their anti-diabetic activity, TZDs display several pleiotropic effects including anti-inflammatory and antioxidant actions that may have potential benefits for AF prevention [10, 11]. However, inconsistent results have been reported regarding TZDs use and AF incidence [12-18]. In light of such conflicting data, we performed a 
comprehensive meta-analysis to evaluate the present evidence and investigate whether the use of TZDs confers benefits in preventing AF.

\section{Methods}

This systematic review was conducted according to the Quality of Reports of Meta-Analyses of Randomized Controlled Trials (QUOROM) recommendations [19] and the guidelines of the Meta-analysis of Observational Studies in Epidemiology Group (MOOSE) [20].

\section{Inclusion criteria}

The studies considered for this meta-analysis were either randomized clinical trials (RCTs) or observational studies that investigated the potential effects of TZDs on AF. The inclusion criteria were as follows: $R C T s: 1)$ randomized controlled human trials with a parallel design; 2) comparison of TZDs with control; 3) collecting data on new or recurrent AF during follow-up. Observational Studies: 1) comparison of TZDs with control; 2) evaluating new or recurrent $\mathrm{AF}$ as an outcome. In the studies of interventions with TZDs no limit in the length of follow-up period was set due to the paucity of relevant studies.

\section{Search strategies}

A systematic literature search was performed by two investigators (Z. Z. and X. Z.) using the online databases of PubMed and Embase to identify relevant studies published before December 2016. The following key terms were used: "thiazolidinediones", "pioglitazone", "rosiglitazone", "troglitazone", and "atrial fibrillation". Both investigators independently evaluated the search results and identified potential studies for further assessment. Disagreements were resolved by a third reviewer (T. L.).

\section{Quality assessment and data extraction}

As quality scoring in meta-analyses of RCTs and observational studies is controversial, several key points of study quality were assessed according to a critical review checklist of Wynn et al. [21]. The key points of this checklist and quality assessments of included studies are listed in Table 1.

Two investigators (Z. Z. and X. Z.) independently extracted the relevant data using a pre-defined spreadsheets. The extracted data elements of the meta-analysis included information on the inclusion criteria, publication details, study design, follow-up duration, daily dosage of TZDs, definition of AF, methods of AF detection, baseline patient characteristics, the variables of multivariate model used in observational studies and results. Disagreements were resolved through discussion or consensus with a third reviewer (T. L.).

\section{Statistical analysis}

Results of the AF outcome are expressed as odds ratio (OR) with 95\% confidence interval (CI) for each study using generic inverse-variance method. The hazard ratio value using multivariate Cox proportional hazards model in the primary study was directly considered as OR [22]. Raw event numbers were extracted from the RCTs and adjusted effect estimates from the observational studies to calculate the overall effects. Statistical heterogeneity was assessed by the $x^{2}$ test and quantified by using the $\mathrm{I}^{2}$ statistic. An $\mathrm{I}^{2}>50 \%$ is indicative of at least moderate heterogeneity [23]. A random-effects model was used. Subgroup analyses regarding AF subtypes (new onset AF

Table 1 Quality assessments of included studies

\begin{tabular}{|c|c|c|c|c|c|c|c|c|c|c|}
\hline Study, year & $\begin{array}{l}\text { Study } \\
\text { type }\end{array}$ & $\begin{array}{l}\text { Randomisation } \\
\text { Method }\end{array}$ & Blinding & $\begin{array}{l}\text { Eligibility } \\
\text { criteria } \\
\text { reported }\end{array}$ & $\begin{array}{l}\text { Study Population } \\
\text { representative of } \\
\text { normal practice }\end{array}$ & $\begin{array}{l}\text { Method of } \\
\text { follow-up } \\
\text { properly } \\
\text { defined }\end{array}$ & $\begin{array}{l}\text { Equal follow-up } \\
\text { between } \\
\text { groups }\end{array}$ & $\begin{array}{l}\text { Was loss to } \\
\text { follow-up } \\
\text { reported } \\
\text { or explained }\end{array}$ & $\begin{array}{l}\text { Prospective } \\
\text { recruitment }\end{array}$ & $\begin{array}{l}\text { Consecutive } \\
\text { recruitment }\end{array}$ \\
\hline $\begin{array}{l}\text { PROactive, } \\
2005 \text { [12] }\end{array}$ & $\mathrm{RCT}$ & $\begin{array}{l}\text { Randomised } \\
\text { permuted blocks }\end{array}$ & Double & Yes & Yes & Yes & Yes & Yes & Yes & Yes \\
\hline $\begin{array}{l}\text { Anglade, } \\
2007 \text { [13] }\end{array}$ & $\begin{array}{l}\text { Case } \\
\text { control }\end{array}$ & NA & NA & Yes & Yes & Yes & Yes & $\begin{array}{l}\text { No loss to } \\
\text { follow-up }\end{array}$ & No & Yes \\
\hline $\begin{array}{l}\text { RECORD, } \\
2009 \text { [14] }\end{array}$ & $\mathrm{RCT}$ & $\begin{array}{l}\text { Randompermuted } \\
\text { blocks }\end{array}$ & None & Yes & Yes & Yes & Yes & Yes & Yes & Yes \\
\hline Gu, 2011 [15] & Cohort & NA & NA & Yes & Yes & Yes & Yes & $\begin{array}{l}\text { No loss to } \\
\text { follow-up }\end{array}$ & Yes & Yes \\
\hline $\begin{array}{l}\text { Chao, } 2012 \\
{[16]}\end{array}$ & $\begin{array}{l}\text { Case } \\
\text { control }\end{array}$ & NA & NA & Yes & Yes & Yes & Yes & $\begin{array}{l}\text { No loss to } \\
\text { follow-up }\end{array}$ & No & Yes \\
\hline Liu, 2014 [17] & $\mathrm{RCT}$ & Computer & Double & Yes & Yes & Yes & Yes & $\begin{array}{l}\text { No loss to } \\
\text { follow-up }\end{array}$ & Yes & Yes \\
\hline $\begin{array}{l}\text { Pallisgaard, } \\
2016 \text { [18] }\end{array}$ & Cohort & NA & NA & Yes & Yes & Yes & Yes & $\begin{array}{l}\text { No loss to } \\
\text { follow-up }\end{array}$ & Yes & Yes \\
\hline
\end{tabular}


or recurrent AF), different TZDs (solely pioglitazone or solely rosiglitazone), study designs (RCTs or observational studies), and different follow-up duration ( $>5$ years or $\leq 5$ years) were additionally performed. Sensitivity analysis was done by removing one study at a time and checking the consequent effects on the effect estimate. Publication bias was evaluated using a funnel plot. Twotailed $p$ values of $<0.05$ were considered statistically significant. The statistical analysis was performed using the Review Manager (RevMan, version 5.3, Copenhagen: The Nordic Cochrane Centre, The Cochrane Collaboration, 2014).

\section{Results}

A total of 346 records were identified initially through our literature search strategy. After careful assessment, seven studies (three RCTs [12, 14, 17] and four observational studies $[13,15,16,18])$ comprising 130,854 diabetic patients $(11,781$ in the treatment and 119,073 in the control group) were included in the final metaanalysis (Fig. 1).

Three studies [12, 15, 17] examined the relationship between pioglitazone use and AF, while two other $[14,16]$ studied rosiglitazone use. The remaining two studies [13, 18] reported data regarding the use of pioglitazone, rosiglitazone and troglitazone. The characteristics of each study are listed in Table 2, and the patients' characteristics in each study are shown in Table 3.

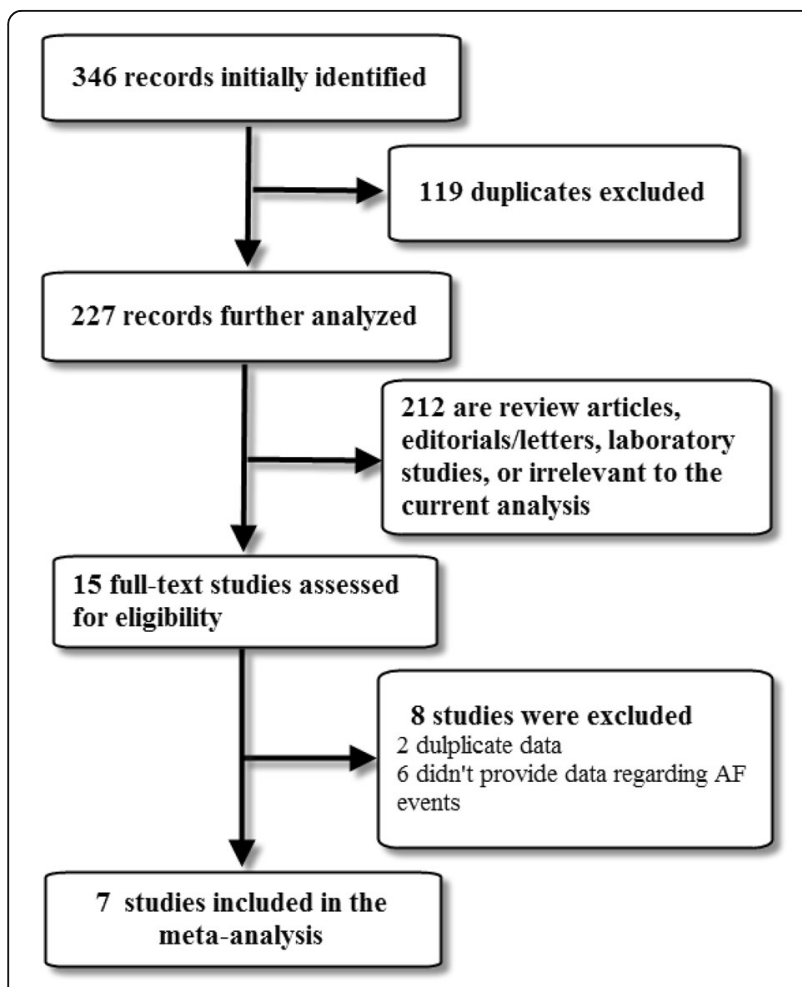

Fig. 1 Flow diagram of the study selection process
Of the seven studies, four [15-18] studies showed that TZDs use attenuated either the risk of new-onset or recurrent AF, whereas the other three [12-14] studies did not indicate a statistically significant difference. Overall, the pooled analysis of the seven included studies suggested that patients treated with TZDs have nearly 30\% lower risk of AF compared with controls (OR $=0.73,95 \%$ $\mathrm{CI}=0.62-0.87, p=0.0003$; Fig. 2). No significant heterogeneity between the individual studies was observed $\left(P=0.36, \mathrm{I}^{2}=9 \%\right)$.

Subgroup analyses according to AF types, different TZDs, follow-up duration, and study designs were subsequently performed (Fig. 2, Table 4). TZDs use was associated with a decrease in the risk of both new-onset $[12,14,16,18] \quad(\mathrm{OR}=0.77,95 \% \mathrm{CI}=0.65-0.91$, $p=0.002)$ and recurrent $\mathrm{AF}[13,15,17](\mathrm{OR}=0.41,95 \%$ $\mathrm{CI}=0.24-0.72,0.002)$ without any heterogeneity across the studies. Regarding different TZDs, pioglitazone use $[12,15,17](\mathrm{OR}=0.56,95 \% \mathrm{CI}=0.32-0.98, p=0.04$; $\left.\mathrm{I}^{2}=54 \%\right)$ was associated with a lower risk of AF incidence, whereas rosiglitazone use $[14,16]$ was not significantly associated with a decreasing AF incidence $(\mathrm{OR}=0.78,95 \%$ $\left.\mathrm{CI}=0.57-1.07, p=0.12 ; \mathrm{I}^{2}=34 \%\right)$. Regarding the subgroup analysis on different follow-up duration, there was no significant difference between the 3 studies $[14,16,18]$ with a follow-up duration $>5$ years $(\mathrm{OR}=0.76,95 \%$ $\left.\mathrm{CI}=0.63-0.91, p=0.002 ; \mathrm{I}^{2}=0 \%\right)$ and the 4 studies $[12$, $13,15,17]$ with a follow-up duration $\leq 5$ years $(\mathrm{OR}=0.62$, $95 \% \mathrm{CI}=0.41-0.94, p=0.02 ; \mathrm{I}^{2}=34 \%$ ). Finally, the pooled analysis of the $4[13,15,16,18]$ observational studies showed a strong association between TZDs use and risk reduction of $\mathrm{AF}(\mathrm{OR}=0.71,95 \% \mathrm{CI}=0.59-0.85$, $p=0.0003 ; \mathrm{I}^{2}=0 \%$, whereas the pooled analysis of the three RCTs showed a non-statistically significant $23 \%$ reduction in the odds of developing AF (OR $=0.77,95 \%$ $\mathrm{CI}=0.53-1.12, p=0.10 ; \mathrm{I}^{2}=40 \%$ ).

Besides, due to different pathophysiologic mechanisms of AF, a sensitivity analysis was performed by removing the studies evaluated post-operation AF [13] and postAF [15] ablation recurrences, no significant differences were found in the heterogeneity $\left(P=0.44 ; \mathrm{I}^{2}=0 \%\right)$ among the remaining five studies $[12,14,16-18]$, and the overall outcome remained the same (OR $=0.75,95 \%$ $\mathrm{CI}=0.64-0.88, p=0.0003)$.

\section{Discussion}

The main findings of this comprehensive meta-analysis on 130,854 diabetic patients are the following: i. TZDs may confer protection against AF incidence; ii. the beneficial effects of TZDs were consistently observed in both new onset and recurrent AF; iii. Pioglitazone use was associated with a statistically reduced risk of incident AF, whereas rosiglitazone use showed no statistically significant difference; and iv. the protective effects of TZDs 
Table 2 The characteristics of 7 included studies

\begin{tabular}{|c|c|c|c|c|c|c|c|c|}
\hline Study, year & $\begin{array}{l}\text { Study } \\
\text { population }\end{array}$ & $\begin{array}{l}\text { Patients } \\
\text { (n) }\end{array}$ & Comparators & $\begin{array}{l}\text { Daily dosage } \\
\text { of TZDs }\end{array}$ & Follow-up & $\begin{array}{l}\text { Definition } \\
\text { of AF }\end{array}$ & $\begin{array}{l}\text { Methods of } \\
\text { AF detection }\end{array}$ & $\begin{array}{l}\text { The variables } \\
\text { of multivariate } \\
\text { model }\end{array}$ \\
\hline $\begin{array}{l}\text { PROactive, } \\
2005 \text { [12] }\end{array}$ & $\begin{array}{l}\text { Patients with } \\
\text { type } 2 \\
\text { diabetes who } \\
\text { had evidence } \\
\text { of } \\
\text { macrovascular } \\
\text { disease }\end{array}$ & 5238 & $\begin{array}{l}\text { Pioglitazone } \\
(n=2605) \text { vs. } \\
\text { placebo } \\
(n=2633)\end{array}$ & $\begin{array}{l}\text { Titrated from } \\
15 \text { to } 45 \mathrm{mg}\end{array}$ & 34.5 months & $\begin{array}{l}\text { New-onset } \\
\text { AF }\end{array}$ & NA & NA \\
\hline $\begin{array}{l}\text { Anglade, } \\
2007 \text { [13] }\end{array}$ & $\begin{array}{l}\text { Diabetic } \\
\text { patients who } \\
\text { underwent } \\
\text { CABG and/or } \\
\text { valvular } \\
\text { surgery }\end{array}$ & 184 & $\begin{array}{l}\text { Pioglitazone } \\
(n=14), \\
\text { rosiglitazone } \\
(n=24) \text { and } \\
\text { troglitazone } \\
(n=2) \text { vs. No TZD } \\
(n=140)\end{array}$ & $\begin{array}{l}\text { Pioglitazone: } \\
\text { average } \\
30 \mathrm{mg} \\
\text { Rosiglitazone: } \\
\text { average } \\
6 \mathrm{mg} \text {, } \\
\text { Troglitazone: } \\
\text { average } \\
525 \mathrm{mg}\end{array}$ & 30 days & $\begin{array}{l}\text { Postoperative } \\
\text { AF }\end{array}$ & NA & NA \\
\hline $\begin{array}{l}\text { RECORD, } \\
2009 \text { [14] }\end{array}$ & $\begin{array}{l}\text { Patients with } \\
\text { type } 2 \\
\text { diabetes }\end{array}$ & 4447 & $\begin{array}{l}\text { Rosiglitazone }+ \\
\text { metformin or } \\
\text { sulfonylurea } \\
\text { ( } n=2220) \text { vs. } \\
\text { metformin and } \\
\text { sulfonylurea } \\
(n=2227)\end{array}$ & $\begin{array}{l}\text { Titrated from } \\
4 \text { to } 8 \mathrm{mg}\end{array}$ & 5.5 years & $\begin{array}{l}\text { New-onset } \\
\text { AF }\end{array}$ & NA & NA \\
\hline Gu, 2011 & $\begin{array}{l}\text { Type } 2 \\
\text { diabetic } \\
\text { patients with } \\
\text { paroxysmal AF } \\
\text { undergoing } \\
\text { catheter } \\
\text { ablation }\end{array}$ & 161 & $\begin{array}{l}\text { Pioglitazone } \\
(n=51) \text { vs. No } \\
\text { pioglitazone } \\
(n=99)\end{array}$ & $30 \mathrm{mg}$ & $22.9 \pm 5.1$ months & $\begin{array}{l}\text { Recurrent ATa } \\
\text { (AF, AT, AFL) }\end{array}$ & $\begin{array}{l}\text { ECG and } \\
\text { Holter } \\
\text { recording }\end{array}$ & $\begin{array}{l}\text { Duration of PAF, } \\
\text { LAD, treatment } \\
\text { with ACEI/ARB }\end{array}$ \\
\hline $\begin{array}{l}\text { Chao, } 2012 \\
\text { [16] }\end{array}$ & $\begin{array}{l}\text { Patients with } \\
\text { non-insulin } \\
\text { dependent } \\
\text { diabetes. }\end{array}$ & 12,065 & $\begin{array}{l}\text { Rosiglitazone } \\
(n=4137) \text { vs. No } \\
\text { rosiglitazone } \\
(n=7928)\end{array}$ & NA & $63 \pm 25$ months & New-onset AF & NA & $\begin{array}{l}\text { Age, HTN, CAD, } \\
\text { chronic renal } \\
\text { disease and use } \\
\text { of statins or } \\
\text { alpha-glucosidase } \\
\text { inhibitors }\end{array}$ \\
\hline $\begin{array}{l}\text { Liu, } 2014 \\
{[17]}\end{array}$ & $\begin{array}{l}\text { Diabetic } \\
\text { patients with } \\
\text { the first } \\
\text { presence of } \\
\text { persistent AF }\end{array}$ & 146 & $\begin{array}{l}\text { Pioglitazone } \\
(n=70) \text { vs. } \\
\text { placebo }(n=76)\end{array}$ & $30 \mathrm{mg}$ & 20.1 months & Recurrent AF & $\begin{array}{l}\text { ECG, history } \\
\text { of } \\
\text { arrhythmia- } \\
\text { related } \\
\text { symptoms, } \\
\text { and Holter } \\
\text { monitoring }\end{array}$ & NA \\
\hline $\begin{array}{l}\text { Pallisgaard, } \\
2016 \text { [18] }\end{array}$ & $\begin{array}{l}\text { Diabetic } \\
\text { patients of } \\
\text { Danish } \\
\text { nationwide } \\
\text { registries }\end{array}$ & 108,624 & $\begin{array}{l}\text { TZD }(n=2658) \text { vs. } \\
\text { other second-line } \\
\text { antidiabetic drugs } \\
(n=105,966)\end{array}$ & NA & 12 years & $\begin{array}{l}\text { New-onset } \\
\text { AF }\end{array}$ & NA & $\begin{array}{l}\text { Age, sex, stroke, HF, } \\
\text { all cancer, } \\
\text { hyperthyroidism, IHD, } \\
\text { COPD, CKD, } \\
\text { liver disease, vascular } \\
\text { disease, HTN, } \\
\text { statin use, prior CABG, } \\
\text { and prior PCl }\end{array}$ \\
\hline
\end{tabular}

Abbreviations: $A F$ atrial fibrillation, PAF paroxysmal atrial fibrillation, $A T a$ atrial tachyarrhythmias, $A T$ atrial tachycardia, $A F L$ atrial flutter, ECG electrocardiograph, $C A B G$ coronary artery bypass graft, TZDs thiazolidinediones, $L A D$ left atrial diameter, $A C E l$ angiotensin converting enzyme inhibitor, $A R B$ angiotensin receptor blocker, HTN hypertension, CAD coronary arterial disease, IHD ischaemic heart disease, COPD chronic obstructive pulmonary disease, CKD chronic kidney disease, $\mathrm{PCl}$ percutaneous coronary intervention, NA not applicable

were only observed in the pooled analysis of the observational studies rather than the RCTs.

The PROactive [12] and RECORD [14] RCTs showed that pioglitazone or rosiglitazone use does not provide any benefit in preventing AF incidence among high-risk patients with type $2 \mathrm{DM}$. However, in these two RCTs, AF was reported as an adverse event rather than a predefined endpoint. Furthermore, these trials displayed a very low AF incidence in both intervention and control groups (1.5-2\%), and thus AF detection may be underpowered. 
Zhang et al. BMC Cardiovascular Disorders (2017) 17:96

Page 5 of 9

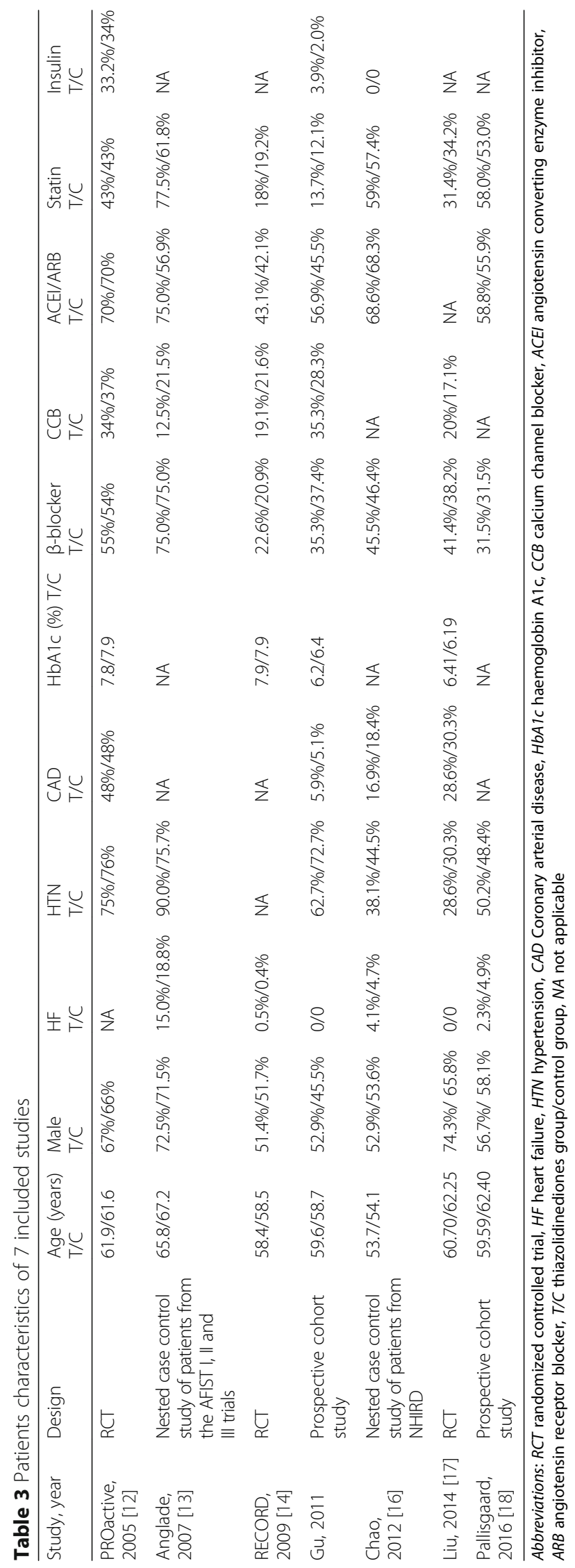




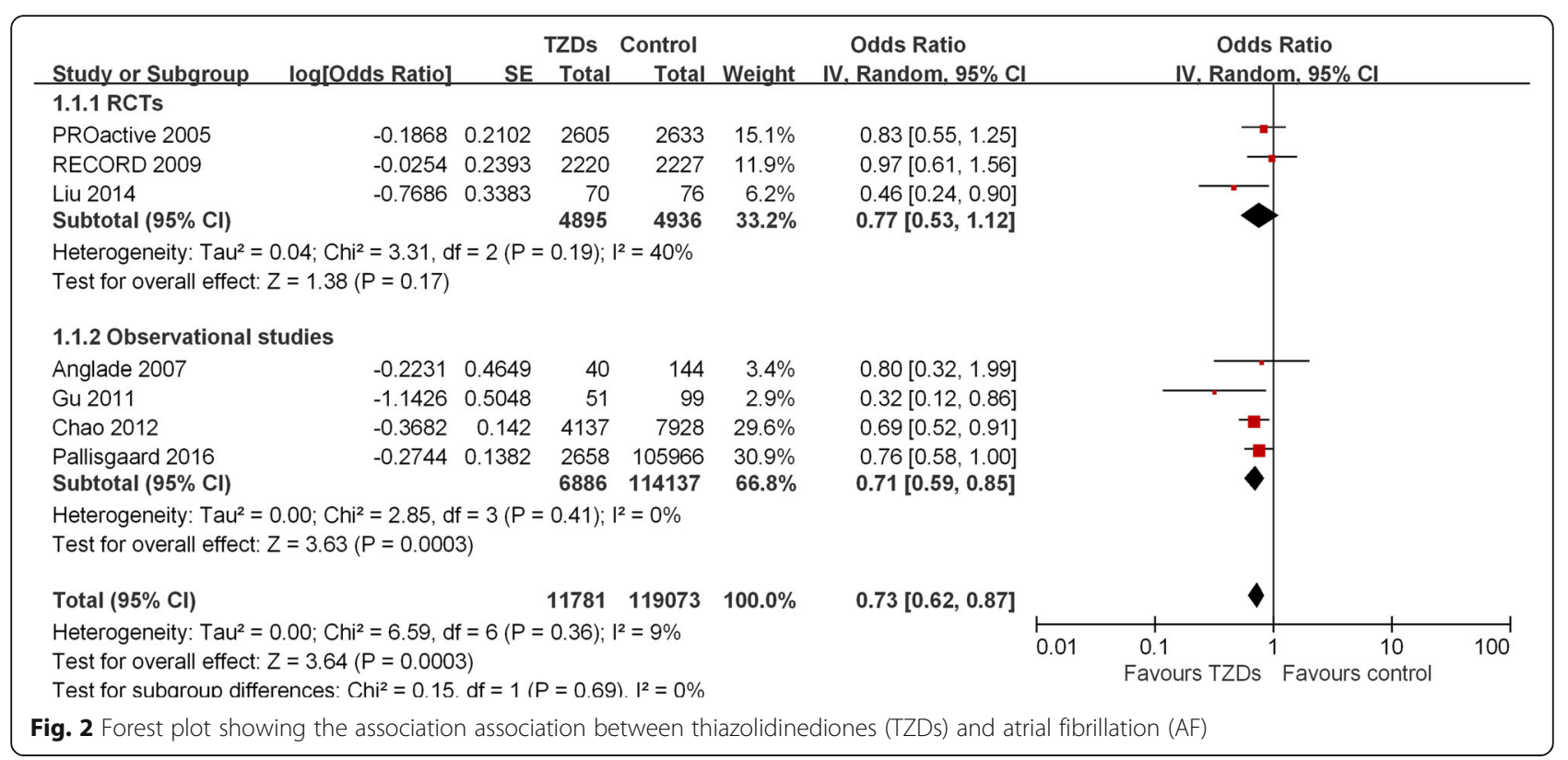

Moreover, in the present meta-analysis, we observed that pioglitazone use was associated with beneficial effects on AF prevention compared with rosiglitazone use. Similarly, previous study suggested that pioglitazone has a beneficial effect on cardiovascular disease, whereas rosiglitazone seemed to increase cardiovascular risk [24]. By assembling a diabetic cohort of older than 65 years, Winkelmayer et al. [25] demonstrated greater risk of mortality and congestive heart failure among patients who initiated therapy with rosiglitazone compared with pioglitazone, however, there were no differences in their incidences of myocardial infarction or stroke. Previous data [26] also showed similar effects on glycemic control between pioglitazone and rosiglitazone, as well as on other parameters such as $\mathrm{C}$-reactive protein (CRP), plasminogen activator inhibitor-1 and indices of insulin secretion and sensitivity. However, pioglitazone treatment was associated with greater beneficial changes on plasma lipids than rosiglitazone treatment [26], which may partly explain the advantage of pioglitazone in reducing AF incidence.

Recently, the IRIS trial [27] demonstrated that pioglitazone can prevent fatal or nonfatal stroke or myocardial infarction among patients who have insulin resistance along with cerebrovascular disease. However, the underlying mechanism for these beneficial effects of pioglitazone remains incompletely elucidated. $\mathrm{AF}$ is a known risk factor of morbidity and mortality by predisposing to strokes and acute coronary syndrome [28]. Thus, it is possible to postulate that pioglitazone reduces the stroke or MI events partly through the reduction of AF burden.

Accumulating evidence supports the role of inflammation and immune response activation in the genesis and perpetuation of AF in different clinical settings, including cardiac surgery, electrical cardioversion and catheter ablation [29]. Oxidative stress has been suggested to play

Table 4 Subgroup analyses of the association between TZDs and AF

\begin{tabular}{|c|c|c|c|c|c|c|c|}
\hline \multirow[t]{2}{*}{ Subgroup } & \multirow[t]{2}{*}{ Study } & \multirow{2}{*}{$\begin{array}{l}\text { Number of } \\
\text { studies }\end{array}$} & \multicolumn{2}{|c|}{ Heterogeneity } & \multicolumn{3}{|c|}{ Meta-analysis } \\
\hline & & & $\mathrm{I}^{2}$ & $P$ P-Value & $\overline{\mathrm{OR}}$ & $95 \% \mathrm{Cl}$ & $p$-Value \\
\hline \multirow[t]{2}{*}{ AF types } & New-onset AF & 4 & $0 \%$ & 0.64 & 0.77 & $0.65-0.91$ & 0.002 \\
\hline & Recurrent AF & 2 & $0 \%$ & 0.54 & 0.41 & $0.24-0.72$ & 0.002 \\
\hline \multirow[t]{2}{*}{ TZDs } & Solely pioglitazone & 3 & $54 \%$ & 0.11 & 0.56 & $0.32-0.98$ & 0.04 \\
\hline & Solely rosiglitazone & 2 & $34 \%$ & 0.22 & 0.78 & $0.57-1.07$ & 0.12 \\
\hline \multirow[t]{2}{*}{ Follow-up duration } & $\leq 5$ years & 4 & $34 \%$ & 0.21 & 0.62 & $0.41-0.94$ & 0.02 \\
\hline & $>5$ years & 3 & 0 & 0.47 & 0.76 & $0.63-0.91$ & 0.002 \\
\hline \multirow[t]{2}{*}{ Study design } & RCTs & 3 & $40 \%$ & 0.10 & 0.77 & $0.53-1.12$ & 0.17 \\
\hline & Observational studies & 4 & $0 \%$ & 0.41 & 0.71 & $0.59-0.85$ & 0.0003 \\
\hline
\end{tabular}


an important role in AF incidence [30]. Numerous studies have demonstrated that TZDs may attenuate inflammation and oxidative stress as well as atrial electrophysiological and structural remodeling in different animal models.

In a ventricular tachypacing-induced CHF rabbit model, Shimano et al. [31] showed that pioglitazone prevents atrial structural remodeling and inhibits AF promotion. Also, similarly to candesartan, pioglitazone suppresses transforming growth factor- $\beta 1$ (TGF- $\beta 1$ ) and tumor necrosis factor- $\alpha$ (TNF- $\alpha$ ) expression in atrial tissue, molecules that are inflammatory mediators related to fibrosis-mediated AF incidence [29]. More recently, Kume et al. [32] suggested that pioglitazone effectively attenuates inflammatory profibrotic signals and vulnerability to AF in a pressure overload AF rat model, possibly via its suppression in monocyte chemoattractant protein (MCP-1) expression. PPAR- $\gamma$ agonists have been shown to attenuate Angiotensin II (Ang II) -induced atrial electrical and structural remodeling in cellular models [33]. These effects are mediated by prevention of ICa-L remodeling by inhibiting CAMP responsive element binding protein (CREB) phosphorylation, as well as by suppression of connective tissue growth factor (CTGF) expression and cell proliferation via inhibiting TGF- $\beta 1 / \mathrm{Smad} 2 / 3$ and TGF- $\beta 1 /$ tumor necrosis factor receptor associated factor 6 (TRAF6)/TGF- $\beta$-associated kinase 1 (TAK1) signaling pathways. In addition, Pioglitazone exhibits beneficial effects on Ang II-induced potassium channel remodeling [34]. More recently, Chen et al. [35] further indicated that pioglitazone inhibits Ang IIinduced atrial fibroblasts proliferation through nuclear factor-kB (NF-kB)/TGF- $\beta 1 /$ Toll/IL-1 receptor domaincontaining adaptor inducing IFN- $\beta$ (TRIF)/TRAF6 signaling pathway. Additionally, $\mathrm{Xu}$ et al. [36] suggested that pioglitazone prevents age-related arrhythmogenic atrial remodeling and AF incidence by improving heat shock protein (HSP) 70 expression and antioxidant capacity, and by inhibiting the mitochondrial apoptotic signaling pathway. In an alloxan-induced diabetic rabbit model, we have shown that rosiglitazone attenuates arrhythmogenic atrial structural remodeling and AF incidence via anti-inflammatory and antioxidant effects [37]. In keeping with these findings, the IRIS trial found lower CRP levels in the pioglitazone group than in the placebo group. Indeed, increased CRP levels have been associated with greater risk of AF [38].

Finally, the treatment of hyperglycemia may have favorable effects on AF burden. In other words, treatment of DM may ameliorate atrial remodeling [7]. Haemoglobin A1c levels have been associated with the occurrence and recurrence of $\mathrm{AF}[7,39,40]$, and therefore TZDs may exert their favorable effects through HbA1c level reduction.

\section{Study limitations}

The present meta-analysis has potential limitations. Firstly, due to the small number of included studies we analyzed observational studies and RCTs together while 2 included RCTs reported AF as an adverse event rather than a predefined endpoint, and the favorable effects of TZDs use on preventing AF incidence were predominately driven by observational studies, whereas data from the 2 RCTs were unable to draw unanimous conclusion. Secondly, information regarding methods of AF detection, cardiac substrate, ejection fraction and atrial volume were not fully presented in our analysis due to the lack of relative data. Thirdly, the heterogeneous types of patient populations (ranging from uncomplicated type 2

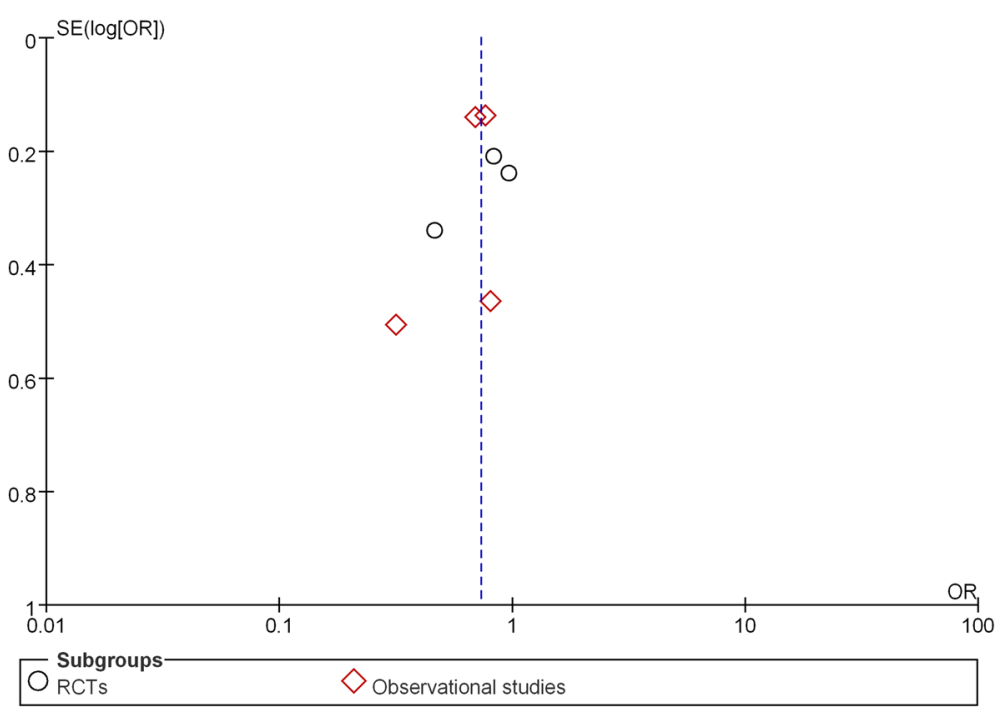

Fig. 3 Funnel plot of meta-analysis 
diabetics to post-CABG or post-AF ablation patients) may indicate latent bias in this meta-analysis. Fourthly, "gray" literature (primarily conference abstracts/presentations, ongoing studies, communication with investigators) was not searched. Finally, the results of the funnel plot suggested that publication bias may be present, although the small number of studies made this somewhat difficult to interpret (Fig. 3).

\section{Conclusions}

In summary, this meta-analysis suggests that TZDs may be effective in AF prevention in the setting of DM. Therefore, TZDs may be considered as the treatment of choice in diabetic patient with high risk features for AF incidence. Since the overall conclusion was mainly drawn from the observational studies, further large-scale prospective RCTs that assessed AF as a predefined outcome are needed to determine whether TZDs use could prevent $\mathrm{AF}$ in the setting of DM.

\section{Abbreviations}

AF: Atrial fibrillation; CHF: Congestive heart failure; Cl: Confidence interval; CRP: C-reactive protein; DM: Diabetes mellitus; OR: Odds ratio; PPAR- $\gamma$ : Peroxisome proliferator-activated receptor-y; RCTs: Randomized clinical trials; TZDs: Thiazolidinediones

\section{Acknowledgments}

Not applicable.

\section{Funding}

This work was supported by grants $(81,570,298,30,900,618,81,270,245$ to T.L.) from the National Natural Science Foundation of China, Tianjin Natural Science Foundation (16JCZDJC34900 to TL).

\section{Availability of data and materials}

All data generated or analysed during this study are included in this published article.

\section{Authors' contributions}

ZZ and ZX participated in study design, searched databases, extracted and assessed data, carried out the statistical analysis and drafted the manuscript. LM and MG performed statistical analyses. TL and GL conceived the design of the study, selected the included studies and drafted the review. KP, KPL and GT revised the manuscript. All authors read and approved the final manuscript.

\section{Competing interests}

The authors declare that they have no competing interests.

\section{Consent for publication}

Not applicable.

\section{Ethics approval and consent to participate} Not applicable.

\section{Publisher's Note}

Springer Nature remains neutral with regard to jurisdictional claims in published maps and institutional affiliations.

\section{Author details}

${ }^{1}$ Tianjin Key Laboratory of Ionic-Molecular Function of Cardiovascular Disease Department of Cardiology, Tianjin Institute of Cardiology, Second Hospital of Tianjin Medical University, No. 23 Pingjiang Road, Hexi District, Tianjin 300211, People's Republic of China. 'First Department of Cardiology, University of Ioannina Medical School, Ioannina, Greece. ${ }^{3}$ Second
Department of Cardiology, Laboratory of Cardiac Electrophysiology, "Evangelismos" General Hospital of Athens, Athens, Greece. ${ }^{4}$ Department of Medicine and Therapeutics, Faculty of Medicine, Chinese University of Hong Kong, Hong Kong, SAR, People's Republic of China. ${ }^{5}$ Li KaShing Institute of Health Sciences, Faculty of Medicine, Chinese University of Hong Kong, Hong Kong, SAR, People's Republic of China.

Received: 28 October 2016 Accepted: 1 April 2017

Published online: 05 April 2017

\section{References}

1. Chugh SS, Havmoeller R, Narayanan K, Singh D, Rienstra M, Benjamin EJ, et al. Worldwide epidemiology of atrial fibrillation: a global burden of disease 2010 study. Circulation. 2014;129(8):837-47.

2. Huxley RR, Filion KB, Konety S, Alonso A. Meta-analysis of cohort and casecontrol studies of type 2 diabetes mellitus and risk of atrial fibrillation. Am J Cardiol. 2011;108(1):56-62

3. Tse G, Lai ET, Tse V, Yeo JM. Molecular and electrophysiological mechanisms underlying cardiac arrhythmogenesis in diabetes mellitus. J Diabetes Res. 2016

4. Soran H, Younis N, Currie P, Silas J, Jones IR, Gill G. Influence of diabetes on the maintenance of sinus rhythm after a successful direct current cardioversion in patients with atrial fibrillation. QJM. 2008;101(3):181-7.

5. Du X, Ninomiya T, de Galan B, Abadir E, Chalmers J, Pillai A, et al. Risks of cardiovascular events and effects of routine blood pressure lowering among patients with type 2 diabetes and atrial fibrillation: results of the ADVANCE study. Eur Heart J. 2009;30(9):1128-35.

6. Zhang Q, Liu T, Ng CY, Li G. Diabetes mellitus and atrial remodeling: mechanisms and potential upstream therapies. Cardiovasc Ther. 2014;32(5): 233-41.

7. Goudis CA, Korantzopoulos P, Ntalas IV, Kallergis EM, Liu T, Ketikoglou DG. Diabetes mellitus and atrial fibrillation: Pathophysiological mechanisms and potential upstream therapies. Int J Cardiol. 2015;184:617-22.

8. Tse G, Yan BP, Chan YW, Tian XY, Huang Y. Reactive oxygen species, endoplasmic reticulum stress and mitochondrial dysfunction: the link with cardiac arrhythmogenesis. Front Physiol. 2016;7:313.

9. Inzucchi SE, Maggs DG, Spollett GR, Page SL, Rife FS, Walton V, et al. Efficacy and metabolic effects of metformin and troglitazone in type II diabetes mellitus. N Engl J Med. 1998;338(13):867-72.

10. Liu T, Li G. Thiazolidinediones as novel upstream therapy for atria fibrillation in diabetic patients: a review of current evidence. Int J Cardiol. 2012:156(2):215-6

11. Liu C, Liu T, Li G. Pioglitazone may offer therapeutic advantages in diabetesrelated atrial fibrillation. Int J Cardiol. 2013:168(2):1603-5.

12. Dormandy JA, Charbonnel B, Eckland DJ, Erdmann E, Massi-Benedetti M, Moules IK, et al. Secondary prevention of macrovascular events in patients with type 2 diabetes in the PROactive study (PROspective pioglitAzone clinical trial in macroVascular events): a randomised controlled trial. Lancet. 2005;366(9493):1279-89

13. Anglade MW, Kluger J, White CM, Aberle J, Coleman Cl. Thiazolidinedione use and post-operative atrial fibrillation: a US nested case-control study. Curr Med Res Opin. 2007;23(11):2849-55.

14. Home PD, Pocock SJ, Beck-Nielsen H, Curtis PS, Gomis R, Hanefeld M, et al. Rosiglitazone evaluated for cardiovascular outcomes in oral agent combination therapy for type 2 diabetes (RECORD): a multicentre, randomised, open-label trial. Lancet. 2009;373(9681):2125-35.

15. Gu J, Liu X, Wang X, Shi $H$, Tan $H$, Zhou L, et al. Beneficial effect of pioglitazone on the outcome of catheter ablation in patients with paroxysmal atrial fibrillation and type 2 diabetes mellitus. Europace. 2011; 13(9):1256-61.

16. Chao TF, Leu HB, Huang CC, Chen JW, Chan WL, Lin SJ, et al. Thiazolidinediones can prevent new onset atrial fibrillation in patients with non-insulin dependent diabetes. Int J Cardiol. 2012;156(2):199-202.

17. Liu B, Wang J, Wang G. Beneficial effects of pioglitazone on retardation of persistent atrial fibrillation progression in diabetes mellitus patients. Int Heart J. 2014:55(6):499-505.

18. Pallisgaard JL, Lindhardt TB, Staerk L, Olesen JB, Torp-Pedersen C, Hansen $\mathrm{ML}$, et al. Thiazolidinediones are associated with a decreased risk of atrial fibrillation compared with other antidiabetic treatment: a nationwide cohort study. Eur Heart J Cardiovasc Pharmacother; 2016. https://doi.org/10.1093/ ehjcvp/pvw036. [Epub ahead of print]. 
19. Moher D, Cook DJ, Eastwood S, Olkin I, Rennie D, Stroup DF. Improving the quality of reports of meta-analyses of randomised controlled trials: the QUOROM statement. Quality of reporting of meta-analyses. Lancet. 1999; 354(9193):1896-900.

20. Stroup DF, Berlin JA, Morton SC, Olkin I, Williamson GD, Rennie D, et al. Meta-analysis of observational studies in epidemiology: a proposal for reporting. Meta-analysis of observational studies in epidemiology (MOOSE) group. JAMA. 2000;283(15):2008-12.

21. Wynn GJ, Das M, Bonnett LJ, Panikker S, Wong T, Gupta D. Efficacy of catheter ablation for persistent atrial fibrillation: a systematic review and meta-analysis of evidence from randomized and nonrandomized controlled trials. Circ Arrhythm Electrophysiol. 2014;7(5):841-52.

22. Greenland S. Quantitative methods in the review of epidemiologic literature. Epidemiol Rev. 1987;9:1-30.

23. Higgins JP, Thompson SG, Deeks JJ, Altman DG. Measuring inconsistency in meta-analyses. BMJ. 2003;327(7414):557-60.

24. Simo R, Rodriguez A, Caveda E. Different effects of thiazolidinediones on cardiovascular risk in patients with type 2 diabetes mellitus: pioglitazone versus rosiglitazone. Curr Drug Saf. 2010;5(3):234-44.

25. Winkelmayer WC, Setoguchi S, Levin R, Solomon DH. Comparison of cardiovascular outcomes in elderly patients with diabetes who initiated rosiglitazone vs pioglitazone therapy. Arch Intern Med. 2008;168(21):2368-75.

26. Goldberg RB, Kendall DM, Deeg MA, Buse JB, Zagar AJ, Pinaire JA, et al. A comparison of lipid and glycemic effects of pioglitazone and rosiglitazone in patients with type 2 diabetes and dyslipidemia. Diabetes Care. 2005;28(7): 1547-54.

27. Kernan WN, Viscoli CM, Furie KL, Young LH, Inzucchi SE, Gorman M, et al. Pioglitazone after ischemic stroke or transient ischemic attack. N Engl J Med. 2016;374(14):1321-31.

28. Stewart S, Hart CL, Hole DJ, McMurray JJ. A population-based study of the long-term risks associated with atrial fibrillation: 20-year follow-up of the Renfrew/paisley study. Am J Med. 2002;113(5):359-64.

29. Hu YF, Chen YJ, Lin YJ, Chen SA. Inflammation and the pathogenesis of atrial fibrillation. Nat Rev Cardiol. 2015;12(4):230-43.

30. Korantzopoulos P, Kolettis TM, Galaris D, Goudevenos JA. The role of oxidative stress in the pathogenesis and perpetuation of atrial fibrillation. Int J Cardiol. 2007;115(2):135-43.

31. Shimano M, Tsuji Y, Inden Y, Kitamura K, Uchikawa T, Harata S, et al. Pioglitazone, a peroxisome proliferator-activated receptor-gamma activator, attenuates atrial fibrosis and atrial fibrillation promotion in rabbits with congestive heart failure. Heart Rhythm. 2008:5(3):451-9.

32. Kume O, Takahashi N, Wakisaka O, Nagano-Torigoe Y, Teshima Y, Nakagawa $\mathrm{M}$, et al. Pioglitazone attenuates inflammatory atrial fibrosis and vulnerability to atrial fibrillation induced by pressure overload in rats. Heart Rhythm. 2011;8(2):278-85.

33. Gu J, Liu X, Wang QX, Guo M, Liu F, Song ZP, et al. Beneficial effects of pioglitazone on atrial structural and electrical remodeling in vitro cellular models. J Mol Cell Cardiol. 2013;65:1-8.

34. Gu J, Hu W, Liu X. Pioglitazone improves potassium channel remodeling induced by angiotensin II in atrial myocytes. Med Sci Monit Basic Res. 2014; 20:153-60.

35. Chen XQ, Liu X, Wang QX, Zhang MJ, Guo M, Liu F, et al. Pioglitazone inhibits angiotensin II-induced atrial fibroblasts proliferation via NF-kappaB/ TGF-beta1/TRIF/TRAF6 pathway. Exp Cell Res. 2015;330(1):43-55.

36. Xu D, Murakoshi N, Igarashi M, Hirayama A, Ito Y, Seo Y, et al. PPAR-gamma activator pioglitazone prevents age-related atrial fibrillation susceptibility by improving antioxidant capacity and reducing apoptosis in a rat model. J Cardiovasc Electrophysiol. 2012;23(2):209-17.

37. Liu T, Zhao H, Li J, Korantzopoulos P, Li G. Rosiglitazone attenuates atrial structural remodeling and atrial fibrillation promotion in alloxan-induced diabetic rabbits. Cardiovasc Ther. 2014;32(4):178-83.

38. Liu T, Li G, Li L, Korantzopoulos P. Association between C-reactive protein and recurrence of atrial fibrillation after successful electrical cardioversion: a meta-analysis. J Am Coll Cardiol. 2007;49(15):1642-8.

39. Huxley RR, Alonso A, Lopez FL, Filion KB, Agarwal SK, Loehr LR, et al. Type 2 diabetes, glucose homeostasis and incident atrial fibrillation: the atherosclerosis risk in communities study. Heart. 2012;98(2):133-8.

40. Anselmino M, Matta M, D'Ascenzo F, Pappone C, Santinelli V, Bunch TJ, et al. Catheter ablation of atrial fibrillation in patients with diabetes mellitus: a systematic review and meta-analysis. Europace. 2015;17(10):1518-25.

\section{Submit your next manuscript to BioMed Central and we will help you at every step:}

- We accept pre-submission inquiries

- Our selector tool helps you to find the most relevant journal

- We provide round the clock customer support

- Convenient online submission

- Thorough peer review

- Inclusion in PubMed and all major indexing services

- Maximum visibility for your research

Submit your manuscript at www.biomedcentral.com/submit 